Vol. 8(15), pp. 588-598, 17 April, 2014

DOI: 10.5897/JMPR2013.5272

ISSN 1996-0875

Copyright (C) 2014

Journal of Medicinal Plant Research

Author(s) retain the copyright of this article

http://www.academicjournals.org/JMPR

Full Length Research Paper

\title{
Cytotoxic and cytogenetic effects of Convolvulus arvensis extracts on rhabdomyosarcoma (RD) tumor cell line in vitro
}

\author{
Asaad Abdulwahed Bader AL-Asady ${ }^{1 \star}$, Dhamia Kasem Suker ${ }^{2}$ and Kawthar Kalaf Hassan ${ }^{3}$ \\ ${ }^{1}$ School of Medicine, Faculty of Medicine, Duhok University, Iraq. \\ ${ }^{2}$ Department of Biology, College of Science, Basrah University, Iraq. \\ ${ }^{3}$ College of Medicine, Basrah University, Iraq.
}

Received 6 October, 2014; Accepted 4 April, 2014

\begin{abstract}
The present study was designed to investigate the cytotoxicity of (aqueous and methanol) crude extracts of the leaves, stems and roots extracts as well as proteoglycan and glycoside fraction I (FI) of Convolvulus arvensis against human Rhabdomyosarcoma (RD) tumor cell line in vitro. The effect of glycoside FI fraction on mitotic index (MI) of RD cell line was investigated as well. The optical density (OD) of cell growth was measured by Elisa reader at $492 \mathrm{~nm}$ using tetrazolium bromide (MTT). Aqueous and methanol leaves extracts and glycoside FI had more cytotoxic effects at $10 \mathrm{mg} / \mathrm{ml}$ after $24 \mathrm{~h}$. After $48 \mathrm{~h}$, proteoglycan and glycoside $\mathrm{FI}$ at $10 \mathrm{mg} / \mathrm{ml}$ revealed very high cytotoxic activity compared with other concentrations. After $72 \mathrm{~h}$, glycoside $\mathrm{Fl}$ at $10 \mathrm{mg} / \mathrm{ml}$ had more cytotoxic inhibition compared with other extracts. Glycoside FI had cytotoxicity concentration $50 \%$ (CC 50\%) 1.775, 0.870 and $0.706 \mathrm{mg} / \mathrm{ml}$ after 24, 48, and $72 \mathrm{~h}$, respectively. The root aqueous extract had less cytotoxic effect after $72 \mathrm{~h}$ than other extracts; the CC $50 \%$ was $7.437 \mathrm{mg} / \mathrm{ml}$. Cytotoxicity of root aqueous extract was more pronounced at higher concentration of $10 \mathrm{mg} / \mathrm{ml}$. The effect of glycoside FI on MI of RD tumor cell line was concentration dependant.
\end{abstract}

Key words: Cytotoxicity, cytogenetics, Convolvulus arvensis, rhabdomyosarcoma (RD) tumor cell line, mitotic index (MI), tetrazolium bromide (MTT).

\section{INTRODUCTION}

Herbal medicine has a vital role in the prevention and treatment of cancer. A great deal of pharmaceutical research output in advanced countries has considerably improved the quality of the herbal medicines used in treatment of cancer (World Health Organization (WHO), 2002). The Convolvulaceae family includes a large number of important plants which have many chemical compounds that are used for treating many diseases (Jacobs and NRCS, 2007).
Convolvulus species are widely distributed all over the world in different localities; some of them have medicinal activity (Abdel-Raheim et al., 2011), such as anticancer, anti-ulcerogenic and antidiarrhoeal. Some species also have a broad activity against some bacteria and fungi (Dhingra and Valecha, 2007). Convolvulus arvensis is an example of a medicinal plant with high therapeutic activities. C. arvensis is evaluated as a potential new source of antioxidant activity (Mohammed et al., 2011).

*Corresponding author. E-mail: Alasady.asaad@uod.ac. Tel: 009647504711189.

Author(s) agree that this article remain permanently open access under the terms of the Creative Commons Attribution

License 4.0 International License 
The antioxidant activity of $C$. arvensis extracts is mainly due to phenolic contents such as flavonoids, phenolic acids, tannins and phenolic diterpenes (Awaad and Jaber, 2010; Thakral et al., 2010). C. arvensis may be a promising source of anticancer agents (Thane et al., 2000). Different extracts of $C$. arvensis affect tumor angiogenesis and immune cell function that stimulate immune cells (Kidd, 2000). Angiogenesis inhibitors derived from natural sources include flavonoids, sulphated carbohydrates and triterpenoids (Paper, 1998). Bind weed extract which contains angiogenesissuppressing proteoglycan molecules (PGMs) regulates the production of a potent angiogenesis inhibitor, interleukin 12. All the previous researches revealed that no study has been carried out on cytotoxicity and cytogenetic effects of different extracts of $C$. arvensis on rhabdomyosarcoma (RD) tumor cell line. Therefore the present study was conducted to evaluate the cytotoxic effects of eight of extracts of $C$. arvensis and cytogenetic effect of glycoside FI leaves fraction of $C$. arvensis on this cell line.

\section{MATERIALS AND METHODS}

\section{Aqueous extracts}

An aqueous extract from leaves, stems or roots of $C$. arvensis was prepared according to Harborne (1984). Fifty grams of the dried ground leaves, stems or roots were macerated with $200 \mathrm{ml}$ water over night, at $45^{\circ} \mathrm{C}$. After $24 \mathrm{~h}$, the extractive solution was filtered in a double layer of gauze then through filter paper (Whitman No.1). The pooled extract was evaporated to dryness at $45^{\circ} \mathrm{C}$ under reduced pressure in a rotary evaporator (Orem Sceentific LtdSwiss). The yield of crude extract was weighted and kept at $-20^{\circ} \mathrm{C}$ until use. Half gram of resultant extract was dissolved into $10 \mathrm{ml}$ phosphate buffer saline (PBS). The suspension was filtered and sterilized by using two sterile Millipore filter papers, 0.45 and $0.22 \mu \mathrm{m}$ and was kept in deep freeze at $-20^{\circ} \mathrm{C}$ as a stock solution until use.

\section{Methanol crude extracts of $\mathrm{C}$. arvensis}

Leaves, stems and root methanol extracts were prepared according to Lin et al. (2010). Fifty gram of each part was refluxed with $250 \mathrm{ml}$ of absolute methanol at $60^{\circ} \mathrm{C}$ for $4 \mathrm{~h}$. The supernatant was separated from the solid residue using Whitman No.1 filter paper. The extraction was repeated twice. The extracts were combined and evaporated at $60^{\circ} \mathrm{C}$ under reduced pressure. After drying, $0.5 \mathrm{~g}$ of the resultant extract was dissolved in $10 \mathrm{ml}$ PBS. The suspension was filtered and sterilized using both 0.45 and $0.22 \mu \mathrm{m}$ sterile Millipore filter paper and was kept in deep freeze at $-20^{\circ} \mathrm{C}$ as a stock solution until use.

\section{Extraction and fractionation of glycosides from leaves of $\mathrm{C}$.} arvensis

Glycosides were separated and fractionated according to Menemen et al. (2002). The resultant extract was filtered and evaporated to dryness under reduced pressure in a rotary evaporator (Orem Scientific Ltd., Swiss). To a fractionation of glycoside, the dried glycoside extract was dissolved in $80 \%$ methanol and was run by thin layer chromatography (TLC) using silica gel in n-butanol:acetic acid:water (BAW), 5:1:4 as eluent. The glycoside spots were examined and their position and color reactions recorded and finally the rate of flow $\left(R_{f}\right)$ values were recorded. To obtain a large amount of fractions, we used the protocol of Menemen et al. (2002). Half gram of the $\mathrm{Fl}$ was dissolved in $10 \mathrm{ml}$ of $1 \%$ dimethyl sulfoxide (DMSO) and the suspension filtered and sterilized using $0.45 \mu$ then a $0.22 \mu$ sterile Millipore filter paper kept in deep freeze $-20^{\circ} \mathrm{C}$ as a stock solution to be used later.

\section{Extraction of proteoglycan molecules (PGM) from leaves of C. arvensis}

The dried powder of $C$. arvensis leaves was mixed in dry weight (DW) at a concentration of $0.16 \mathrm{~g} / \mathrm{ml}$ to prepare the proteoglycan as described previously (Meng et al., 2002). The resultant product was lyophilized to produce the extract powder which is referred to as PGM. $0.5 \mathrm{gm}$ of resultant extract was dissolved in $10 \mathrm{ml}$ PBS and the suspension filtered and sterilized using $0.45 \mu \mathrm{m}$ then a $0.22 \mu \mathrm{m}$ sterile Millipore filter paper, and finally kept in deep freeze $-20^{\circ} \mathrm{C}$ as a stock solution until use.

\section{Chemical tests}

Alkaloids in plant extracts were determined using Wagner's and Dragendorff tests (Harborne, 1984), whereas tannins were determined using ferric chloride and lead acetate solutions (Harborne, 1984). Flavonoids was tested according to AL-Shahaat (1986). Liebermann-Burchard test was used for triterpenoids. Peptides and free amino groups tests were used for peptides, primary or secondary amino groups (Harborne, 1984). Molish reagent test was used for carbohydrate (Hawk et al., 1954). The presence of glycosides was detected according to AL-Shahaat (1986). Saponins were identified according to Harborne (1984). Biuret test was used to detect protein (Saadalla, 1980).

\section{Cell lines}

Rhabdomyosarcoma (RD) was provided by Iraqi Center for Cancer and Medical Genetic Research/Baghdad (ICCMGR). Passage number 45 was used and the cells were cultivated in minimum essential medium (MEM) with L-Glutamine and HEPES (Sigma, USA) which was supplemented with $10 \%$ of fetal calf serum and penicillin/streptomycin. The following formula was followed to calculate viability of the cell lines using 1\% Trypan blue stain (Fine Chemical, Sweden Pharmac): $C=N \times D \times 10^{4}$, where $C$ is the number of viable cells per milliliter, $\mathrm{N}$ is the number of viable cells counted, and $D$ is the dilution factor $(D=10)$ (Fresheny, 1994).

Effect of aqueous and methanol crude extracts of leaves, stems, root, proteoglycan and glycoside (FI) extracts of $C$. arvensis on growth of RD tumor cell line

About $200 \mu$ of RD cells passage (45) were suspended $(55,000$ cells $/ \mathrm{ml}$ ) in growth medium. These cells were seeded into each well of a sterile 96-wells micro-titration plate. The plates were sealed with a self-adhesive film, lids were placed on and incubated at $37^{\circ} \mathrm{C}$ in $5 \% \mathrm{CO}_{2}$ incubator. When the cells are in exponential growth (approximately 70 to $80 \%$ confluent monolayer) after $72 \mathrm{~h}$, the medium was removed and serial dilutions of each aqueous, methanol crude extracts of $C$. arvensis in free serum MEM medium were added to the wells. The same was applied for glycoside (FI) and proteoglycan (PGM) separately. The dilutions were 10, 5, 2.5, $1.250,0.5,0.313,0.156$ and $0.078 \mathrm{mg} / \mathrm{ml}$, respectively. Three replicates were used for each concentration of each extract. Three wells were used for seeding cells in medium alone, another three 


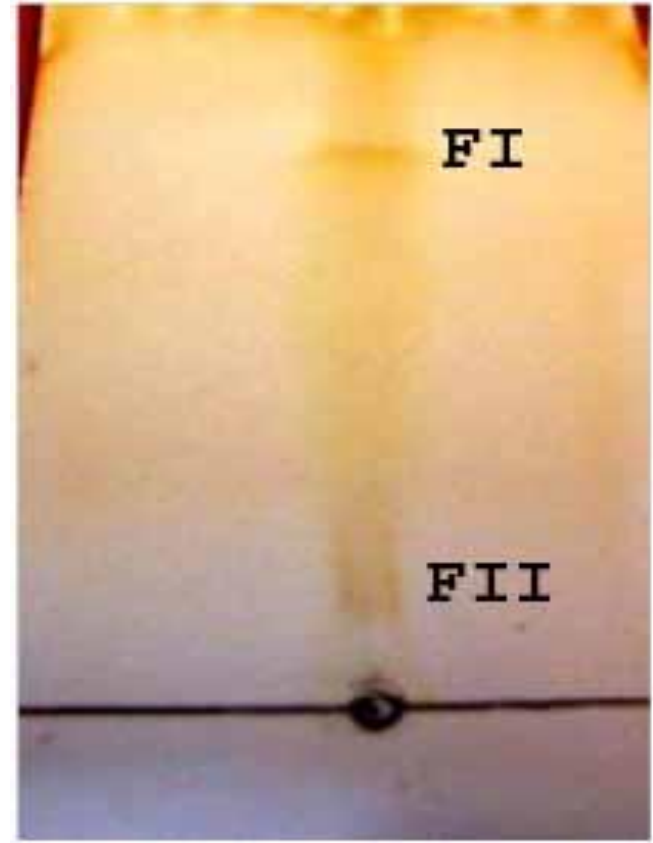

Figure 1. TLC of glycoside fractions developed by $\mathrm{H}_{2} \mathrm{SO}_{4}$.

wells for seeding cells in medium with PBS and three wells for seeding in medium with DMSO $1 \%$ final concentration; we confirmed that this DMSO concentration did not affect the proliferation of $\mathrm{RD}$ cell line. The plates were re-incubated at $37^{\circ} \mathrm{C}$ for the selected exposure times (24, 48, and $72 \mathrm{~h}$ ). After 24,48 and $72 \mathrm{~h}$ of exposure to each extract, the medium was removed and $28 \mu \mathrm{l}$ of [3(4, 5-Dimethyl thiazol-2-yl) 2-5-Diphenyl-tetrazolium bromide] MTT (Sigma) were added to the wells. The plates were incubated in $\mathrm{CO}_{2}$-incubator for $2 \mathrm{~h}$ at $37^{\circ} \mathrm{C}$. At the end of incubation, the excess dye was removed and $130 \mu \mathrm{l}$ of DMSO was added to each well to solubilize and extract the dye from the viable cells. Then, the plates were placed on a shaker for $15 \mathrm{~min}$. The optical density (OD) of each well after treatment was read using enzyme linked immunosorbent assay (ELISA) reader at a transmitting wavelength of 492 $\mathrm{nm}$ (Betancur-Galvis et al., 2002). The percentage of cytotoxicity was calculated as $(A-B) / A \times 100$, where $A$ means $O D$ of untreated wells and $B$ is the $O D$ of wells with plant extracts (Betancur-Galvis et al., 1999). The cytotoxic concentration 50\% (CC 50\%) for each extract was calculated from concentration-effect-curves after linear regression analysis (Hayslett and Patrick, 1981).

\section{Cytogenetic effect of glycoside (FI) extract on RD tumor cell line}

Cultures of RD tumor cell line (three replicates) were used for treatment with glycoside $\mathrm{FI}$ extract since it was a more effective extract to determine the mitotic index (MI). The concentrations of glycoside $\mathrm{FI}$ were $0.353,0.176$ and $0.088 \mathrm{mg} / \mathrm{ml}$, which were selected according to the cytotoxicity tests (less than CC $50 \%$ ). Another set of three culture flasks were used to maintain the media with $1 \%$ DMSO only as a negative control. Flasks were incubated at $37^{\circ} \mathrm{C}$ for $72 \mathrm{~h}$ (Modi et al., 1987). Culture in the flask was re-fed with pre-warmed fresh medium $6 \mathrm{~h}$ before adding colcemide solution to obtain a final concentration of $1 \mu \mathrm{g} / \mathrm{ml}$ and incubated at $37^{\circ} \mathrm{C}$ for half an hour. Slides were prepared according to Modi (1987) and stained by using 2\% Giemsa stain (Merck, USA) for 2.5 min and rapidly washed with Sorenson's buffer and then left to dry at room temperature. Microscopical examination under $40 \times$ objective lens was followed to detect the MI. One thousand cells were examined in each slide to calculate the MI. The MI\% was determined as a ratio of the mitotic cells in metaphase to the total cells.

$\mathrm{Ml} \%=($ No. of dividing cells $/$ No. of dividing cells + No. of nondividing cells) $\times 100$ (Kleinsmith, 2006).

\section{Statistical analysis}

The results were evaluated by the analysis of the variance (ANOVA), $P$-values at levels $(P \leq 0.01)$ were considered to be statistically significant and this calculation was carried out according to statistical package for social science (SPSS, version 19). The least significant difference (LSD) at the level less than 0.05 were used to determine the significant differences between levels of each factor (Steel and Torrie, 1980).

\section{RESULTS}

\section{Qualitative chemical analysis of $C$. arvensis extracts}

The results of qualitative chemical analysis of $C$. arvensis (aqueous and methanol) crude extracts from (leaves, stems and roots), methanol glycosides (FI and FII) and aqueous proteoglycan from leaves with respect to the yield of extractions \% are summarize in Tables 1 and 2 .

\section{Thin layer chromatography (TLC) of methanol leaves extract of C. arvensis}

The results of TLC for methanol leaves extract of $C$. arvensis showed the presence of two brown color spots; the color was developed by $\mathrm{H}_{2} \mathrm{SO}_{4}$ as shown in Figure 1 . These two spots were different in the rate of flow $\left(R_{\mathrm{f}}\right)$. $\mathrm{FI}$ $=0.8$ and $\mathrm{FII}=0.187$ (Table 3).

\section{Spectrophotometer analysis}

The result of fractions of glycosides from leaves of $C$. arvensis showed two peak of Fractions I and II at $\lambda=450$ nm (Figure 2).

\section{Fourier transforms infra-red (FTIR) spectroscopy analysis of glycoside fractions}

Infrared spectrum for glycoside fractions $\mathrm{FI}$ and $\mathrm{FII}$ extracted from $C$. arvensis leaves are shown in Figures 3 and 4 and the results were illustrated in Table 4.

\section{Melting point}

The melting point of Fraction I was at $160^{\circ} \mathrm{C}$, but the melting point of fraction II was not detected due to its viscous nature. 


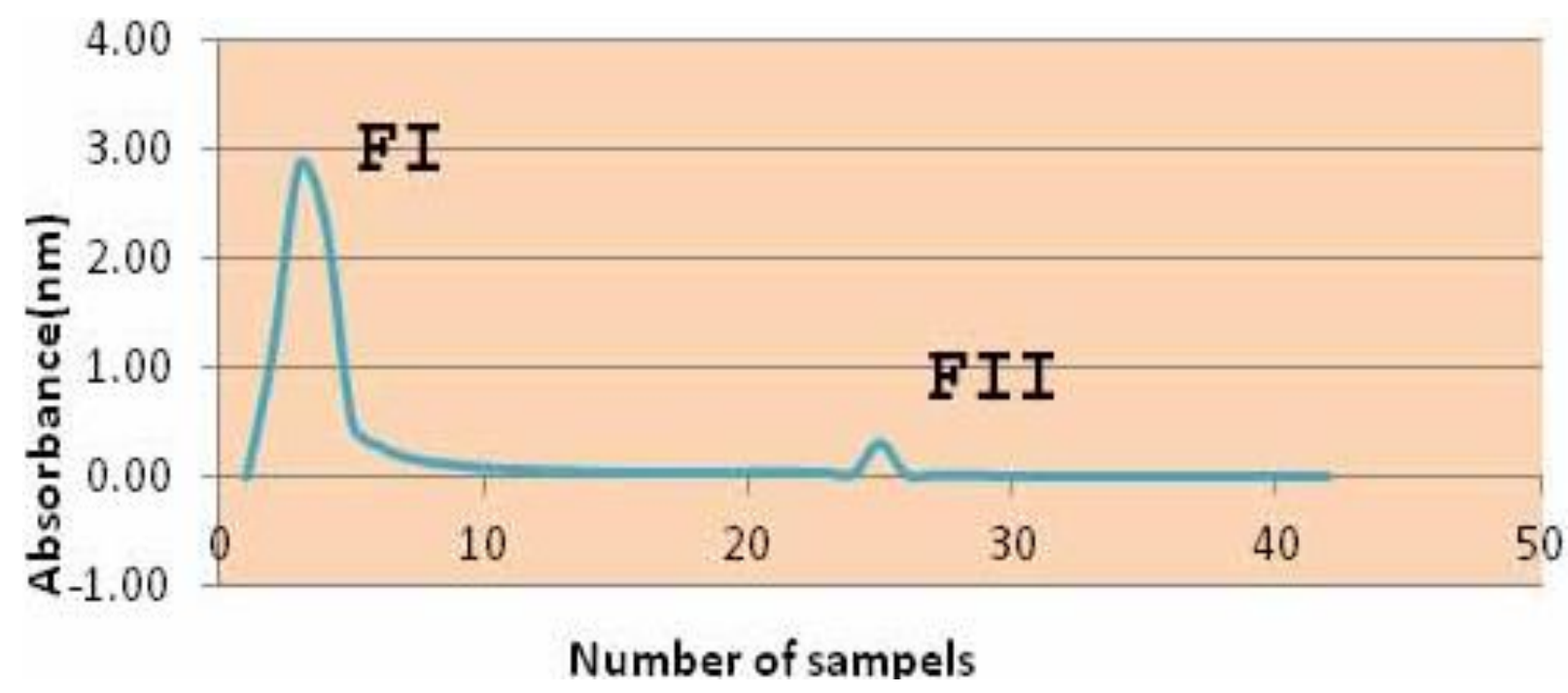

Figure 2. Silica gel chromatography of glycosides extracts from C. arvensis.

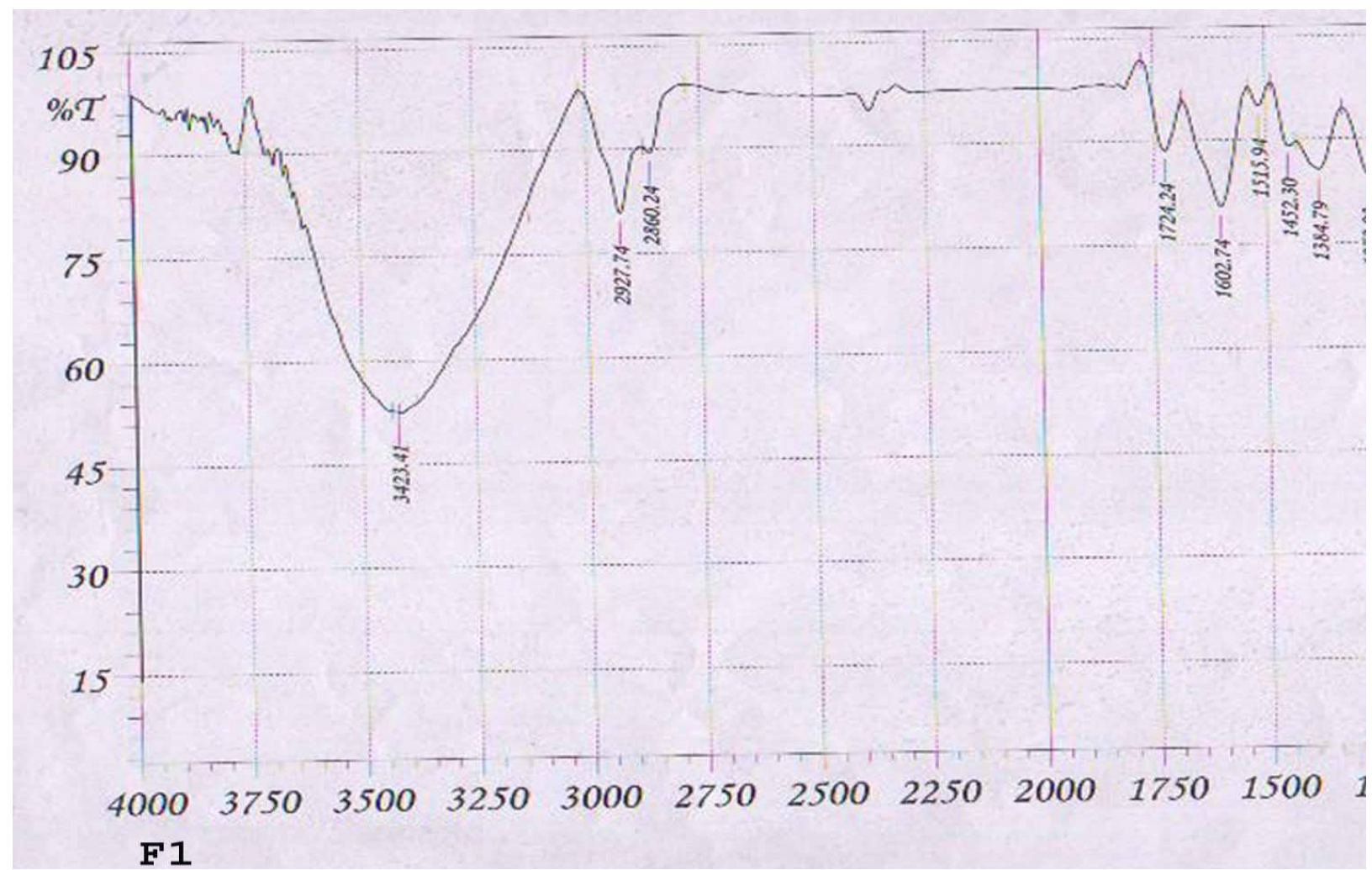

Figure 3. Infrared spectrum for fraction I (FI) of glycoside of C. arvensis leaves extract.

Cytotoxic effects of (aqueous, methanol) crude extracts from leaves, stems and roots (glycoside FI and PGM) from leaves of $C$. arvensis on RD tumor cell lines in vitro

The results show that the effect of glycoside FI, proteoglycan extracts and all crude extracts(leaves, stems and roots) of $C$. arvensis on proliferation of RD tumor cell line was highly significant $(P \leq 0.001)$ in all periods of treatments. The interaction between the effects of extracts and their concentrations was highly significant $(P \leq 0.001)$ after all periods of treatments. The foregoing 


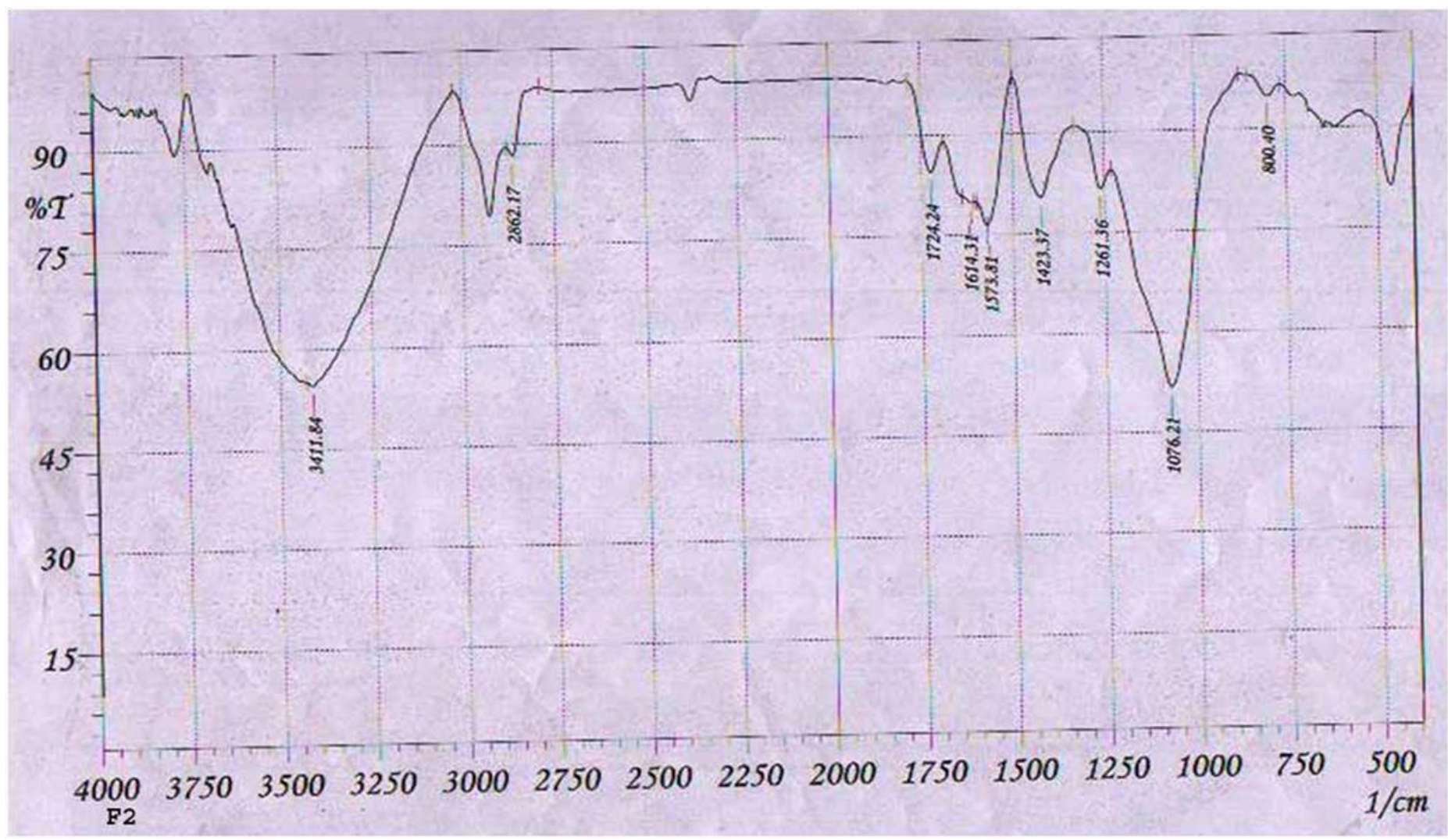

Figure 4. Infrared spectrum for fraction II (FII) of glycoside of $C$. arvensis leaves extract.

Table 1. The yield of extraction \% of $C$. arvensis (aqueous and methanol) crude extracts (leaves, stems and roots), methanol glycosides (FI and FII) and aqueous proteoglycan from leaves.

\begin{tabular}{|c|c|c|c|}
\hline Part of plant & \multicolumn{2}{|l|}{ Type of extract } & Yield of extraction \% \\
\hline $\mathrm{L}$ & \multicolumn{2}{|l|}{ Methanol } & 19.85 \\
\hline $\mathrm{L}$ & \multicolumn{2}{|l|}{ Aqueous } & 12.37 \\
\hline L & \multicolumn{2}{|l|}{ Proteoglycan } & 9.28 \\
\hline \multirow{2}{*}{ L } & \multirow{2}{*}{ Glycosides } & $\mathrm{F} 1$ & 4.22 \\
\hline & & $\mathrm{F} 2$ & 0.21 \\
\hline S & Methanol & & 13.27 \\
\hline S & Aqueous & & 11.06 \\
\hline $\mathrm{R}$ & Methanol & & 15.38 \\
\hline $\mathrm{R}$ & Aqueous & & 9.80 \\
\hline
\end{tabular}

L: leaf, S: stem R: root.

foregoing results indicate that the toxicity of the leaves stems and roots extracts varied with different types of extracts and concentrations. The concentrations of leaves methanol, leaves aqueous extracts and glycoside FI $10 \mathrm{mg} / \mathrm{ml}$ after $24 \mathrm{~h}$ show significant effect on growth of RD tumor cell line (Table 5) as compared to the control group which shows complete confluent monolayer of cohesive malignant cells. The effect of each stems aqueous extract, proteoglycan and stem methanol extract at 10 $\mathrm{mg} / \mathrm{ml}$ was less than that of leaves methanol, leaves aqueous extract and glycoside $\mathrm{Fl}$ at $24 \mathrm{~h}$. Interaction between concentrations and extracts revealed that leaves methanol, leaves aqueous extracts and glycoside $\mathrm{FI}$ extract had the same effect at $10 \mathrm{mg} / \mathrm{ml}$ after $24 \mathrm{~h}$. After $48 \mathrm{~h}$, Table 6 shows that the effect of proteoglycan and glycoside $\mathrm{FI}$ against the proliferation of RD cells, especially at $10 \mathrm{mg} / \mathrm{ml}$, was more than the effects of all others extracts. 
Table 2. Qualitative chemical analysis for aqueous and methanol extracts of leaves, stems, roots, glycosides FI, FII and proteoglycan for leaves of $C$. arvensis.

\begin{tabular}{|c|c|c|c|c|c|c|c|c|c|}
\hline \multirow{3}{*}{ Compound group } & \multicolumn{9}{|c|}{ Extract } \\
\hline & \multicolumn{3}{|c|}{ Aqueous } & \multicolumn{3}{|c|}{ Methanol } & \multirow{2}{*}{ Proteoglycan } & \multicolumn{2}{|c|}{ Glycosides } \\
\hline & Leaves & Stem & Root & Leaves & Stem & Root & & $\mathbf{F I}$ & FII \\
\hline \multicolumn{10}{|l|}{ Alkaloids } \\
\hline Wagner's test & + & + & + & + & + & + & - & - & - \\
\hline Dragendorf test & + & + & + & + & + & + & - & - & - \\
\hline \multicolumn{10}{|l|}{ Polyphenol (Tannins) } \\
\hline Lead acetate & + & + & + & + & + & + & - & + & + \\
\hline Ferric chloride & + & + & + & + & + & + & - & - & - \\
\hline \multicolumn{10}{|l|}{ Flavonoid test } \\
\hline Alcoholic $\mathrm{KOH}$ & + & + & + & + & + & + & + & + & + \\
\hline Sulfuric acid & + & + & + & + & + & + & + & + & + \\
\hline Triterpenoid (Liebermann- Burchard test) & - & - & - & - & - & - & - & - & - \\
\hline Peptides free amino group & + & + & + & + & + & + & + & - & - \\
\hline Carbohydrate (Molish test) & + & + & + & + & + & + & + & + & + \\
\hline \multicolumn{10}{|l|}{ Glycosides (Benedict) } \\
\hline Before hydrolysis & + & + & + & + & + & + & + & + & + \\
\hline After hydrolysis & + & + & + & + & + & + & + & + & + \\
\hline Saponins & + & + & + & + & + & - & - & - & - \\
\hline Protein (Biuret test) & - & - & - & - & - & - & + & - & - \\
\hline \multicolumn{10}{|l|}{ Polyphenol (Tannins) } \\
\hline Lead acetate & + & + & + & + & + & + & - & + & + \\
\hline Ferric chloride & + & + & + & + & + & + & - & - & - \\
\hline
\end{tabular}

$+=$ The extract contain the designated phytochemicals. ; - = The extract does not contain the designated phytochemicals.

Table 3. Thin layer chromatography for glycosides ( $\mathrm{t}$ and color of spots).

\begin{tabular}{cccc}
\hline \multicolumn{2}{c}{ Compound } & Rate of flow (Rf) & Color of spot \\
\hline \multirow{2}{*}{ Glycosides } & FI & 0.8 & Brown \\
& FII & 0.187 & Brown \\
\hline
\end{tabular}


Table 4. The main functional groups and their frequencies in FTIR of fraction I and fraction II.

\begin{tabular}{|c|c|c|c|c|}
\hline \multicolumn{2}{|c|}{ Band frequency $\left(\mathrm{cm}^{-1}\right)$} & \multirow{2}{*}{ Group } & \multirow{2}{*}{ Mode of vibration } & \multirow{2}{*}{ Functional group } \\
\hline $\mathbf{F I}$ & FII & & & \\
\hline 3423 (br) & 3411 (br) & $-\mathrm{OH}$ & Stretch & Hydroxyl \\
\hline 2927 & 2927 & $\mathrm{C}-\mathrm{H}$ & Stretch & $\mathrm{CH} 3$ \\
\hline 1724 & 1724 & $\mathrm{C}=\mathrm{O}$ & Stretch & Carboxyl group \\
\hline 1602 & 1614 & $\mathrm{C}=\mathrm{C}$ & Stretch & Ring \\
\hline 1515 & 1573 & $\mathrm{C}=\mathrm{C}$ & stretch & Ring \\
\hline 1452 & 1423 & $\mathrm{C}-\mathrm{H}$ & Asymmetric bending & $\mathrm{CH} 3$ \\
\hline 1384 & - & $-\mathrm{OH}$ & Bend in plane & Hydroxyl \\
\hline 1272 & 1261 & $\mathrm{C}-\mathrm{O}-\mathrm{C}$ & Asymmetric stretch & Ether \\
\hline 1070 & 1076 & $\mathrm{C}-\mathrm{O}-\mathrm{C}$ & Symmetrical stretch & Ether group \\
\hline
\end{tabular}

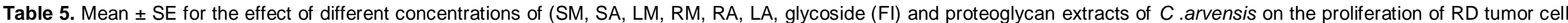
line after $24 \mathrm{~h}$ treatments in vitro (observations of OD).

\begin{tabular}{|c|c|c|c|c|c|c|c|c|c|}
\hline \multirow{2}{*}{ Extracts } & \multicolumn{9}{|c|}{ Concentration $\mathrm{mg} / \mathrm{ml}$} \\
\hline & 0 & 0.078 & 0.156 & 0.312 & 0.625 & 1.25 & 2.5 & 5 & 10 \\
\hline Stem methanolic & $0.739 \pm 0.001$ & $0.741 \pm 0.003$ & $0.739 \pm 0.017$ & $0.734 \pm 0.007$ & $0.736 \pm 0.01$ & $0.734 \pm 0.025$ & $0.645 \pm 0.009$ & $0.599 \pm 0.006$ & $0.588 \pm 0.012$ \\
\hline Stem aqueous & $0.739 \pm 0.004$ & $0.744 \pm 0.028$ & $0.737 \pm 0.003$ & $0.725 \pm 0.003$ & $0.718 \pm 0.006$ & $0.558 \pm 0.005$ & $0.549 \pm 0.01$ & $0.550 \pm 0.002$ & $0.546 \pm 0.018$ \\
\hline Proteoglycan & $0.739 \pm 0.021$ & $0.746 \pm 0.008$ & $0.739 \pm 0.002$ & $0.735 \pm 0.017$ & $0.727 \pm 0.0005$ & $0.719 \pm 0.003$ & $0.643 \pm 0.0005$ & $0.582 \pm 0.0005$ & $0.580 \pm 0.013$ \\
\hline Leaves methanolic & $0.794 \pm 0.001$ & $0.793 \pm 0.003$ & $0.778 \pm 0.002$ & $0.778 \pm 0.001$ & $0.776 \pm 0.0008$ & $0.772 \pm 0.006$ & $0.608 \pm 0.0005$ & $0.592 \pm 0.004$ & $0.228 \pm 0.034$ \\
\hline Root methanolic & $0.794 \pm 0.001$ & $0.794 \pm 0.003$ & $0.786 \pm 0.001$ & $0.782 \pm 0.001$ & $0.762 \pm 0.001$ & $0.751 \pm 0.002$ & $0.731 \pm 0.002$ & $0.729 \pm 0.0005$ & $0.728 \pm 0.005$ \\
\hline Root aqueous & $0.794 \pm 0.001$ & $0.786 \pm 0.001$ & $0.784 \pm 0.005$ & $0.775 \pm 0.014$ & $0.771 \pm 0.001$ & $0.7630 \pm 0.001$ & $0.760 \pm 0.003$ & $0.7590 \pm 0.001$ & $0.621 \pm 0.009$ \\
\hline Leaves aqueous & $0.765 \pm 0.005$ & $0.759 \pm 0.003$ & $0.757 \pm 0.001$ & $0.756 \pm 0.001$ & $0.751 \pm 0.004$ & $0.749 \pm 0.005$ & $0.707 \pm 0.0005$ & $0.552 \pm 0.002$ & $0.225 \pm 0.03$ \\
\hline Glycoside & $0.747 \pm 0.003$ & $0.751 \pm 0.001$ & $0.731 \pm 0.002$ & $0.227 \pm 0.0005$ & $0.225 \pm 0.0001$ & $0.221 \pm 0.001$ & $0.219 \pm 0.002$ & $0.206 \pm 0.001$ & $0.201 \pm 0.048$ \\
\hline Effectors & Extracts & \multicolumn{2}{|c|}{ Concentration } & \multicolumn{3}{|c|}{ Extract and concentration } & & & \\
\hline LSD (0.05) & 0.006629 & \multicolumn{2}{|c|}{0.007031} & \multicolumn{3}{|c|}{0.019886} & & & \\
\hline
\end{tabular}

$\mathrm{SM}=$ stem methanol, $\mathrm{SA}=$ stem aqueous, $\mathrm{LM}=$ leaves methanol, $\mathrm{RM}=$ root methanol, $\mathrm{RA}=$ root aqueous and $\mathrm{LA}=$ leaves aqueous. $\mathrm{LSD}=$ least significant difference

After $72 \mathrm{~h}$, proteoglycan and glycoside $\mathrm{FI}$ possessed an activity from 0.156 to $10 \mathrm{mg} / \mathrm{ml}$; their activity against the growth of RD cells increased by increasing their concentration. The results showed that glycoside $\mathrm{FI}$ was more effective extract against the proliferation of RD cells especially at $10 \mathrm{mg} / \mathrm{ml}$ where the value of OD was $0.105 \pm 0.002$ (Table 7).

The exposure times had a highly significant effect $(P \leq 0.001)$ on growth of RD tumor cell line treated with stems methanol extract, stems aqueous extract, proteoglycan and leaves aqueous extracts. Leaves and roots methanol extracts had less significant effect $(P \leq 0.01)$. Time was not effective significantly on growth of 


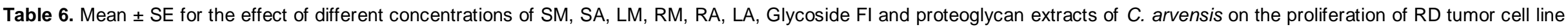
after $48 \mathrm{~h}$ treatments in vitro (observations of $\mathrm{OD}$ ).

\begin{tabular}{|c|c|c|c|c|c|c|c|c|c|}
\hline \multirow{2}{*}{ Extract } & \multicolumn{9}{|c|}{ Concentration $\mathrm{mg} / \mathrm{ml}$} \\
\hline & 0 & 0.078 & 0.156 & 0.312 & 0.625 & 1.25 & 2.5 & 5 & 10 \\
\hline Stem methanolic & $0.803 \pm 0.005$ & $0.787 \pm 0.031$ & $0.749 \pm 0.041$ & $0.584 \pm 0.043$ & $0.575 \pm 0.021$ & $0.557 \pm 0.018$ & $0.399 \pm 0.036$ & $0.390 \pm 0.011$ & $0.209 \pm 0.008$ \\
\hline Stem aqueous & $0.803 \pm 0.005$ & $0.795 \pm 0.009$ & $0.767 \pm 0.027$ & $0.458 \pm 0.0005$ & $0.330 \pm 0.04$ & $0.324 \pm 0.024$ & $0.325 \pm 0.023$ & $0.183 \pm 0.002$ & $0.183 \pm 0.013$ \\
\hline Proteoglycan & $0.803 \pm 0.005$ & $0.803 \pm 0.021$ & $0.673 \pm 0.026$ & $0.705 \pm 0.002$ & $0.372 \pm 0.012$ & $0.371 \pm 0.005$ & $0.372 \pm 0.016$ & $0.094 \pm 0.002$ & $0.077 \pm 0.001$ \\
\hline Leaves methanolic & $0.798 \pm 0.041$ & $0.789 \pm 0.02$ & $0.787 \pm 0.06$ & $0.741 \pm 0.031$ & $0.640 \pm 0.009$ & $0.187 \pm 0.0005$ & $0.172 \pm 0.001$ & $0.155 \pm 0.002$ & $0.153 \pm 0.001$ \\
\hline Root methanolic & $0.798 \pm 0.041$ & $0.798 \pm 0.011$ & $0.797 \pm 0.015$ & $0.766 \pm 0.004$ & $0.754 \pm 0.064$ & $0.631 \pm 0.077$ & $0.231 \pm 0.017$ & $0.225 \pm 0.001$ & $0.222 \pm 0.003$ \\
\hline Root aqueous & $0.798 \pm 0.041$ & $0.788 \pm 0.031$ & $0.787 \pm 0.039$ & $0.776 \pm 0.036$ & $0.770 \pm 0.017$ & $0.766 \pm 0.002$ & $0.764 \pm 0.007$ & $0.761 \pm 0.018$ & $0.446 \pm 0.03$ \\
\hline Leaves aqueous & $0.762 \pm 0.0 .052$ & $0.458 \pm 0.015$ & $0.461 \pm 0.03$ & $0.458 \pm 0.027$ & $0.483 \pm 0.018$ & $0.412 \pm 0.004$ & $0.416 \pm 0.006$ & $0.386 \pm 0.022$ & $0.208 \pm 0.018$ \\
\hline Glycoside & $0.731 \pm 0.002$ & $0.746 \pm 0.003$ & $0.705 \pm 0.002$ & $0.221 \pm 0.001$ & $0.209 \pm 0.002$ & $0.149 \pm 0.0005$ & $0.139 \pm 0.001$ & $0.121 \pm 0.001$ & $0.110 \pm 0.002$ \\
\hline
\end{tabular}

\begin{tabular}{lccc}
\hline Effector & Extract & Concentration & Extracts and concentration \\
\hline LSD $(0.05)$ & 0.02336 & 0.02478 & 0.07009 \\
\hline
\end{tabular}

$\mathrm{SM}=$ stem methanol, $\mathrm{SA}=$ stem aqueous, $\mathrm{LM}=$ leaves methanol, $\mathrm{RM}=$ root methanol, $\mathrm{RA}=$ root aqueous and $\mathrm{LA}=$ leaves aqueous. $\mathrm{LSD}=$ least significant difference

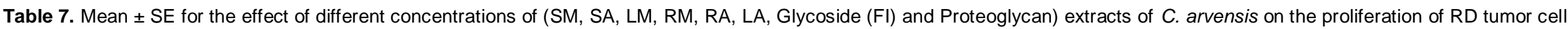
line after $72 \mathrm{~h}$ treatments in vitro (observations of OD).

\begin{tabular}{|c|c|c|c|c|c|c|c|c|c|}
\hline \multirow{2}{*}{ Extracts } & \multicolumn{9}{|c|}{ Concentration $\mathrm{mg} / \mathrm{ml}$} \\
\hline & 0 & 0.078 & 0.156 & 0.312 & 0.625 & 1.25 & 2.5 & 5 & 10 \\
\hline Stem methanolic & $0.756 \pm 0.028$ & $0.756 \pm 0.00$ & $0.436 \pm 0.015$ & $0.317 \pm 0.023$ & $0.225 \pm 0.018$ & $0.201 \pm 0.014$ & $0.216 \pm 0.014$ & $0.216 \pm 0.004$ & $0.156 \pm 0.0005$ \\
\hline Stem aqueous & $0.756 \pm 0.028$ & $0.756 \pm 0.014$ & $0.351 \pm 0.014$ & $0.338 \pm 0.007$ & $0.273 \pm 0.035$ & $0.237 \pm 0.015$ & $0.223 \pm 0.011$ & $0.207 \pm 0.012$ & $0.203 \pm 0.001$ \\
\hline Proteoglycan & $0.756 \pm 0.028$ & $0.755 \pm 0.012$ & $0.489 \pm 0.009$ & $0.340 \pm 0.029$ & $0.204 \pm 0.002$ & $0.174 \pm 0.001$ & $0.170 \pm 0.0005$ & $0.162 \pm 0.001$ & $0.160 \pm 0.001$ \\
\hline Leaves methanolic & $0.794 \pm 0.002$ & $0.783 \pm 0.0008$ & $0.779 \pm 0.005$ & $0.679 \pm 0.002$ & $0.521 \pm 0.002$ & $0.164 \pm 0.001$ & $0.144 \pm 0.002$ & $0.141 \pm 0.001$ & $0.133 \pm 0.002$ \\
\hline Root methanolic & $0.794 \pm 0.002$ & $0.793 \pm 0.001$ & $0.782 \pm 0.001$ & $0.759 \pm 0.003$ & $0.731 \pm 0.005$ & $0.628 \pm 0.002$ & $0.232 \pm 0.0005$ & $0.158 \pm 0.001$ & $0.157 \pm 0.002$ \\
\hline Root aqueous & $0.794 \pm 0.002$ & $0.786 \pm 0.001$ & $0.785 \pm 0.002$ & $0.775 \pm 0.002$ & $0.764 \pm 0.002$ & $0.752 \pm 0.0005$ & $0.697 \pm 0.002$ & $0.571 \pm 0.002$ & $0.196 \pm 0.001$ \\
\hline Leaves aqueous & $0.763 \pm 0.020$ & $0.746 \pm 0.044$ & $0.548 \pm 0.016$ & $0.370 \pm 0.035$ & $0.272 \pm 0.01$ & $0.264 \pm 0.024$ & $0.246 \pm 0.004$ & $0.161 \pm 0.003$ & $0.160 \pm 0.004$ \\
\hline Glycoside & $0.718 \pm 0.001$ & $0.716 \pm 0.001$ & $0.681 \pm 0.001$ & $0.208 \pm 0.002$ & $0.199 \pm 0.001$ & $0.143 \pm 0.001$ & $0.136 \pm 0.002$ & $0.117 \pm 0.001$ & $0.105 \pm 0.002$ \\
\hline
\end{tabular}

\begin{tabular}{lccc}
\hline Effector & Extract & Concentration & Extracts and concentration \\
\hline LSD $(0.05)$ & 0.01215 & 0.01288 & 0.03644 \\
\hline
\end{tabular}

$\mathrm{SM}=$ stem methanolic, $\mathrm{SA}=$ stem aqueous, $\mathrm{LM}=$ leaves methanolic, $\mathrm{RM}=$ root methanolic, $\mathrm{RA}=$ root aqueous, $\mathrm{LA}=$ leaves aqueous. $\mathrm{LSD}=$ least significant difference.

RD cell line when subjected to roots aqueous extract and glycoside FI. Table 8 demonstrated that stems and leaves methanol extracts and proteoglycan were more toxic after $72 \mathrm{~h}$ than 24 and $48 \mathrm{~h}$ on growth of RD cells. However, stems and leaves aqueous extracts, root methanol had the same effect at 48 and $72 \mathrm{~h}$ on growth of these cells and all previous extracts were more effective than $24 \mathrm{~h}$. Glycoside FI had CC 50\% values of 
Table 8. Mean \pm SE for the effect of exposure time to (SM, SA, LM, RM, RA, LA, Glycoside (FI) and proteoglycan) extracts of C.arvensis on the proliferation of RD tumor cells in vitro (observation OD).

\begin{tabular}{lcccc}
\hline \multirow{2}{*}{ Extract } & \multicolumn{3}{c}{ Time $(\mathbf{h})$} & \multirow{2}{*}{ LSD } \\
\cline { 2 - 4 } & $\mathbf{2 4}$ & $\mathbf{4 8}$ & $\mathbf{7 2}$ & 0.0967 \\
Stem methanol & $0.695 \pm 0.005$ & $0.561 \pm 0.038$ & $0.364 \pm 0.043$ & 0.1075 \\
Stem aqueous & $0.652 \pm 0.004$ & $0.463 \pm 0.047$ & $0.372 \pm 0.041$ & 0.1161 \\
Proteoglycan & $0.690 \pm 0.001$ & $0.474 \pm 0.052$ & $0.357 \pm 0.046$ & 0.1440 \\
Leaves methanol & $0.680 \pm 0.004$ & $0.491 \pm 0.058$ & $0.460 \pm 0.057$ & 0.1203 \\
Root methanol & $0.762 \pm 0.004$ & $0.580 \pm 0.051$ & $0.559 \pm 0.053$ & - \\
Root aqueous & $0.757 \pm 0.001$ & $0.739 \pm 0.021$ & $0.680 \pm 0.035$ & 0.1002 \\
Leaves aqueous & $0.669 \pm 0.001$ & $0.449 \pm 0.027$ & $0.392 \pm 0.044$ & - \\
Glycoside & $0.392 \pm 0.002$ & $0.348 \pm 0.053$ & $0.336 \pm 0.051$ & \\
\hline
\end{tabular}

$\mathrm{SE}=$ standard error. $\mathrm{SM}=$ stem methanol, $\mathrm{SA}=$ stem aqueous, $\mathrm{LM}=$ leaves methanol, $\mathrm{RM}=$ root methanol, $\mathrm{RA}=$ root aqueous and $\mathrm{LA}=$ leaves aqueous. $\mathrm{LSD}=$ least significant difference.

Table 9. Mean \pm SE for MI of RD tumor cells after $72 \mathrm{~h}$ treatment with glycoside (FI) extract of $C$. arvensis in vitro.

\begin{tabular}{lcc}
\hline Parameter & Concentration $\mathbf{~ m} / \mathbf{m l}$ & MI\% \\
\hline Control & 0 & $10.34 \pm 0.41$ \\
& 0.353 & $1.93 \pm 0.13$ \\
Glycoside extract & 0.177 & $3.44 \pm 0.29$ \\
& 0.088 & $6.71 \pm 0.68$ \\
L.S.D (0.05) & & \\
\hline
\end{tabular}

$\mathrm{SE}=$ Standard error, LSD = least significant difference.

$1.775,0.870$ and $0.706 \mathrm{mg} / \mathrm{ml}$ after exposure to 24,48 , and $72 \mathrm{~h}$, respectively. The result of cytogenetic analysis showed a decrease in MI of RD tumor cell line treated with concentrations of $0.353,0.177$ and $0.088 \mathrm{mg} / \mathrm{ml}$ of glycoside $\mathrm{Fl}$ extract as compared with control groups $1.93 \pm 0.13,3.44 \pm 0.29,6.71 \pm 0.68$ and $10.34 \pm 0.41$, respectively (Table 9 ).

\section{DISCUSSION}

Cytotoxic effect of (aqueous and methanol) crude extracts, PGM and glycoside FI of $C$. arvensis on RD tumor cell line in vitro

The cytotoxic effect of all extracts of $C$. arvensis on RD tumor cell line varied depending on the extract and its concentration. The results showed that glycoside extract $\mathrm{FI}$ was more effective against the proliferation of RD tumor cell line. This result was supported by Mojab et al. (2003) where it was shown that glycoside components play an important role in cytotoxicity against cancer. The high inhibition activity of glycoside FI extract against the
RD cell line may be explained by different mechanisms. Glycoside extracts had different inhibitory properties on potassium fluxes that clearly inhibit the potassium intake of those cells by inhibition of the Na-KATPase enzyme activity, which in turn leads to significant change in the permeability of the plasma membrane that allow the entry of compounds to the cell and disrupt the nitrogen base sequence of DNA (Chakravarty, 1976). Choi et al. (1994) found the anti-mutagenic capacity of glycoside dependent on free hydroxyl groups. Merfort et al. (1994) concluded that most of glycosides penetrate into human skin, making it a candidate for prevention and treatment of skin cancer.

Koishi et al. (1992) showed that quercitin inhibited production of heat shock proteins in several malignant cell lines, including colon cancer. Heat shock proteins form a complex with mutant $\mathrm{p53}$, which allows tumor cells to bypass normal mechanisms of cell cycle arrest (Ranelletti et al., 1999). The obtained results of glycoside cytotoxicity may be attributed to the inhibition in the production of heat shock proteins. The ability of PGM extract of $C$. arvensis to reduce the proliferation of RD cells was in time-dependent manner, since its activity increased 
after 48 and $72 \mathrm{~h}$, and its effect was started at concentrations of $0.156 \mu \mathrm{g} / \mathrm{ml}$, up to $10 \mathrm{mg} / \mathrm{ml}$. Calvino (2002) prepared a novel proteoglycan mixture (PGM) extract from $C$. arvensis and their results showed that these extracts inhibited tumor growth and angiogenesis in chick embryo and improved lymphocyte. Toxicity of $C$. arvensis may be related to the presence of several types of alkaloids (pseudotropin) or other components of flavonoids, saponins, carbohydrate (AL-Edani, 1998). Winter (2008) showed that alkaloids reduced the proliferation of mouse lymphoblast cell line. Both leaves and stems methanol extracts showed high activity against the proliferation of RD tumor cell line at concentration of $0.156 \mathrm{mg} / \mathrm{ml}$ and up to $10 \mathrm{mg} / \mathrm{ml}$, especially at $72 \mathrm{~h}$. The current results were similar to that obtained by Sadeghialiabadi et al. (2008) where they showed that chloroform, methanol and ethanol extracts of aerial parts of $C$. arvensis possessed high cytotoxic activity on Hela tumor cell line.

Awad et al. (2004) demonstrated that the roots contain low amounts of crude protein (18.7\%), aspartic acid and alanine less than green parts and had high amounts of phenylalanine, which may explain the low activity of roots aqueous extract against the proliferation of RD cell line. Some root compounds have low ability to be absorbed by cell membranes (Marja, 2004). This low activity of root extract may be due to the resistance of the cell lines to its compounds. Lee et al. (2003) found that the tumor cells vary in their response to different drugs or crude extracts according to the types of cell membrane receptors. Our results revealed that the methanol roots extract had more toxicity than roots aqueous extract since the methanol had high polarity which could dissolve both polar and non polar components which then can be actively passed through the plasma membrane. Cannell (1998) and Rajendran and Ramakrishnan (2009) found that the high polarity of methanol extract of Artocarpus heterophyllus was responsible for inhibiting nearly $100 \%$ of Hep2 cells. The other explanation for the differences in cytotoxic activity between aqueous and methanol extracts may be due to the presence of the calystegin alkaloid extracted by methanol (Russel, 1993). A study of Khanavi et al. (2009) supported the obtained results where they found that methanol extract from Stachys species contains the most potent antioxidant and had more activity than the aqueous extract.

\section{Cytogenetic effect of glycoside (FI) extract of $C$. arvensis on the RD tumor cell line in vitro}

The present experiment focused on determining the effect of glycoside $\mathrm{FI}$ extract on $\mathrm{MI}$ of $\mathrm{RD}$ cell line. Rhabdomyosarcoma tumor cell line showed a decrease in $\mathrm{MI}$ when treated with all concentrations $(0.353,0.177$ and $0.088 \mathrm{mg} / \mathrm{ml}$ ) of glycoside $\mathrm{Fl}$ extract as compared with untreated cells (negative control group); their effects were concentration-dependent manner. The ability of glycoside $\mathrm{FI}$ to reduce the $\mathrm{MI}$ of $\mathrm{RD}$ tumor cell line might be explained by its contents of chemical constituents that had ability to reduce cell cycle progression. Amorim et al. (2000) found that the decrease in Ml reflects the inhibition of cell-cycle progression and/or the loss of proliferative capacity. Cell cycle arrest in S-phase was found in human lung squamous carcinoma cells treated with glycoside extract (Leung et al., 2005). Wang et al. (2007) found that the glycoside isolated from two Asian plants Epimedium koreaonum and Terminalia arjuna were traditionally used as anticancer medicines; they inhibit proliferation of MCF-7 (breast cancer) and HepG2 (liver cancer) cells in a dose-dependent manner.

\section{Conclusion}

Fraction I of glycoside caused high inhibition activity on growth of RD cell line after 24, 48 and $72 \mathrm{~h}$. The aqueous roots extract had less inhibiting activity against the growth of RD cells. The Fraction I of glycoside showed high antimitotic effect on RD cell line with concentrations of $0.353,0.177$ and $0.088 \mathrm{mg} / \mathrm{ml}$.

\section{ACKNOWLEDGMENT}

We express our deep appreciation and sincere thanks to the Head and Staff of the Iraqi Center for Cancer and Medical Genetic Research, Baghdad/Iraq. We wish to thank Assist. Prof. Dr. Iqbal J.AL-Assadi, Department of Chemistry, College of Science for her help in interpreting the IR and other biochemical advice.

\section{Conflict of Interests}

The author(s) have not declared any conflict of interests.

\section{REFERENCES}

Abdel-Raheim D, ALQasoumi S, Awaad A, Cracker L (2011). Antioxidant activity of Convolvulus hystrix Vahl and its chemical constituents. Pak. J. Pharm. Sci. 24(2):143-147.

AL-Edani T (1998). A systematic study of family Convolvolaceae Juss in Iraq. PhD. Thesis. Collage of science. University of Basrah.Iraq.

Al-Shahaat N (1986). Plants and medicinal herbs, Dar Al-Behaar Beirut.

Amorim MI, Mergler D, Bahia MO, Dubeau H, Miranda D, Lebel J, Burbano RR, Lucotte M (2000). Cytogenetic damage related to low levels of Methyl mercury contamination in the Brazilian Amazon. An. Acad. Bras. Cienc. 72: 487-507.

Awaad A, Jaber N (2010). Antioxidant natural plant. RPM. Ethnomed. Source Mech. 27:1-35.

Awad H, Wickham M, Leddy H, Gimble J, Guilak F (2004). Chondrogenic differentiation of adipose-derived adult stem cells in agarose, alginate, and gelatin scaffolds. Biomaterials 25:3211-3222.

Betancur-Galvis L, Morales G, Forero J, Roldan J (2002). Cytotoxic and antiviral activity of Colombian medicinal plant extract of the Euphorbia genus. Mem. Inst. Oswaldo Cruz. 97:541-546.

Betancur-Galvis L, Saez J, Granados H, Salazar A, Ossa J (1999). Antitumor and antiviral activity of Colombian medicinal plant extracts. 
Mem. Inst. Oswaldo Cruz. 94(4):101-106.

Calvino NI (2002). Anti angiogenesis properties of a common weed Convolvulus arvensis. Dynamic Chiropractic. $\mathrm{http}: / /$ www.dynamicchiropractic.com/mpacms/dc/article.php?id=1533 0

Cannell R (1998). Natural product isolation, Humana Press, New Jersey, U.K.

Chakravarty H (1976). Plant wealth of Iraq (A dictionary of economic plants) 1. Botany Directorate, Ministry of Agriculture and Agrarian Reform. Baghdad. Iraq.

Choi J, Park K, Moon S, Rhee S, Young H (1994). Antimutagenic effect of plant flavonoids in the Salmonella assay system. Arch. Pharm. Res.17:71-75.

Dhingra D, Valecha R (2007). Evaluation of the antidepressant-like activity of Convolvulus pluricaulis choisy in the mouse forced swim and tail suspension tests. Med. Sci. Monit. 13:155-161.

Fresheny R (1994). Culture of animal cells. A manual of basic technique, 3rd ed. John Wiley and Sons. Inc.,New York.

Harborne J (1984). Phytochemical Methods. 2nd ed. Chapman and Hall, London.

Hawk P, Oser B, Sumerson H (1954). Practical physiological chemistry. $13^{\text {th }}$ ed., McGraw-Hill. Book Comp.

Hayslett H, Patrick M (1981). Statistics. Heinemann. London. p. 246.

Jacobs J, NRCS Invasive Species Specialist (2007). Ecology and management of field bindweed [Convolvulus arvensis L.] Natural resources conservation service Invasive species. Technical Note No.MT-9:1-9

Khanavi M, Hajimahmoodi M, Cheraghi-Niroom M ,Kargar Z, Ajani $Y$, Hadjiakhoondi A, Oveisi M (2009). Comparison of the antioxidant activity and total phenolic contents in some Stachys species, J. Biotechnol. 8(6):1143- 1147.

Kidd $P$ (2000). The use of mushroom glucans and proteoglycans in cancer Treatment. Altern. Med. Rev. 5:4-27.

Kleinsmith L (2006). Principles of cancer biology. San Francisco: Benjamin, Cummings p. 312.

Koishi M, Hosokawa N, Sato M (1992). Quercetin, an inhibitor of heat Shock protein synthesis, inhibits the acquisition of thermotolerance in a human colon carcinoma cell line. Jpn. J. Cancer Res. 83:12161222.

Lee J, Kim J, Park J, Chung G, Jang Y (2003). The antioxidant, rather than prooxidant, activities of quercetin on normal cells: quercetin protects Mouse thymocytes from glucose oxidase-mediated apoptosis. Exp. Cell Res. 291:386-397.

Leung $\mathrm{H}$, Wu C, Lin C, Lee $\mathrm{H}$ (2005). Luteolin induced DNA damage leading to human lung squamous carcinoma $\mathrm{CH} 27$ cell apoptosis. Eur. J. Pharmacol. 508:77-83.

Lin C, Hung J, Linkuo P, Huag Y (2010). Antioxidant and antiproliferative activities of methanolic extracts of Perilla frutescens. J. Med. Plants Res. 416:477-483.

Marja T (2004). The formation and antimicrobial activity of nisin and plant Derived bioactive components in lactic acid bacterial fermentations PhD. Thesis. Faculty of Agriculture and Forestry. University of Helsinki.

Menemen Y, Williams C, Jury S (2002). Flavonoid patterns in Convolvulus L., (Convolvulaceae) species from Morocco. Pak. Bot. 34:291-295
Meng X, Riordan N, Casciari J, Zhu Y, Zhong J, Gonzalez M, MirandaMassari J, Riordan H (2002). Effects of a high molecular mass C.arvensis extract on tumor growth and angiogenesis. P. R. Health Sci. J. 21:323-328.

Merfort I, Heilmann J, Hagedorn-Leweke U, Lippold B (1994). In vivo skin penetration studies on chamomile flavones. Pharmazie 49:509511.

Modi W, Nash W, Ferrari A, O'Brien S (1987). Cytogenetic methodologies for gene mapping and comparative analysis in mammalian cell culture systems. Gene Anal. Technol. 4:75-85.

Mohammed D, AL-Qasoumi S, Awaad A, Cracker L (2011). Antioxidant activity of Convolvulus hystrix Vahl and its chemical constituent's. Pak. J. Pharm. Sci. 24(2):143-147.

Mojab F, Kamalinejad M, Gharder N, Vahidipour H (2003). Phytochemical screening of some species of Iranian plants. Iran. J. Pharmaceut. Res. 2:77-82.

Paper D (1998). Natural products as angiogenesis inhibition. Planta Med. 64:686-695.

Rajendran N, Ramakrishnan J (2009). Polyphenol analysis and antitumor activity of crude extracts from tegmen of Artocarpus heterophyllus. Int. J. Altern. Med. 7:2.

Ranelletti F, Maggiano N, Serra F (1999). Quercetin inhibits p21-ras expression in human colon cancer cell lines and in primary colorectal tumors. Int. J. Cancer 85:438-445.

Russel J, Pan Y, Arlette G, David A, Alan D (1993). Calystegin, a noval class of alkaloid glycosidase inhibitors. Arch. Biochem. Biophys. 304 (1):81-88.

Saadalla R (1980). Biochemistry practical manual. Basrah University press. Basrah-Iraq. p. 54.

Sadeghi-aliabadi H, Ghasemi N, Kohi M (2008). Cytotoxic effect of Convolvulus arvensis extracts on human cancerous cell line. Res. Pharmaceut. Sci. 3(1):31-34.

Steel RGD, Torrie JH (1980). Principles and Procedures of Statistics. $2^{\text {nd }}$ Ed. McGraw-Hill Book Company, New York.

Thakral J, Sakshi B, Roopa A, Kalia N (2010). Antioxidant potential fractionation from methanol extract of aerial parts of Convolvulus arvensis Linn. (Convolvulaceae). Int. J. Pharm. Sci. Drug Res. 2(3):219-223.

Thane U, Bagadey S, Dahanukar S (2000). Modulation of programmed cell death by medicinal plants. Cell Mol. Biol. 46:199-214.

Wang T, Zhang J, Chen Y, Huang F, Yang M, Xiao P (2007). Comparison of antioxidative and antitumor activities of six flavonoids from Epimedium koreanum .Zhongguo Zhong Yao Za Zhi. 32:715718

WHO (2002). Traditional medicine strategy launched. 80:610.

Winter K (2008). Identification of bioactive compounds in wheat. PhD. Thesis, School of Environmental Science and Management. Southern Cross University, Lismore. NSW. 